\title{
JOURNAL.RU
}

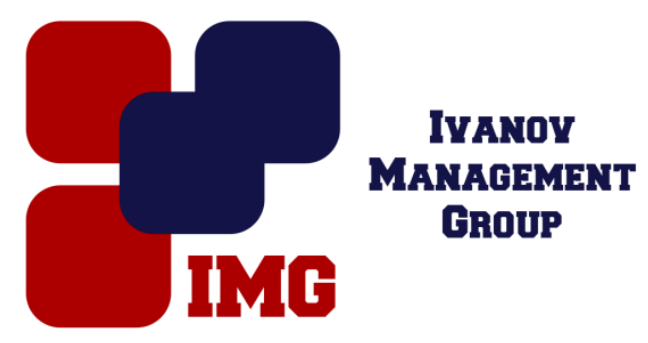

Хасанов Г.М., Залялова А.Р., Ахмерова Г.М. Казанский государственный архитектурно-строительный университет Казань, Россия

doi: 10.18411/1j-30-06-2017-13

idsp 000001:1j-30-06-2017-13

\section{Внедрение ИТП как вариант решения проблемы изношенности системы теплоснабжения}

В 50-х годах XX века, одновременно с началом массового жилищного строительства в СССР, начали появляться центральные тепловые пункты (ЦТП), обслуживающие группы зданий. На сегодняшний день актуальным является массовый переход от ЦТП к индивидуальным тепловым пунктам (ИТП), расположенным в отапливаемых зданиях. Данное решение значительно улучшит эффективность распределения теплоты как в новых домах, так и в уже существующем жилом фонде.

Плюсы внедрения ИТП:

1. Внедрение индивидуальных тепловых пунктов позволит полностью отказаться от распределительных сетей горячего водоснабжения - вода для внутридомовых систем горячего водоснабжения будет приготавливаться в теплообменниках ИТП. Таким образом, можно сразу отказаться от четырёхтрубной схемы подключения объектов теплоснабжения в пользу двухтрубной - а это даст сокращение протяжённости распределительных сетей и, как следствие, уменьшение расходов на их прокладку и эксплуатацию.

2. Внедрение ИТП позволит существенно снизить потери теплоты при транспортировке, основная часть которых приходится как раз на долю распределительных сетей.

3. Использование ИТП способствуют снижению расхода электроэнергии это происходит за счёт отключения насосов на подаче бытовой горячей воды и снижения мощности, необходимой для обеспечения циркуляции теплоносителя. Прокачку внутридомовых систем будут осуществлять насосы ИТП. 
4. Снижение расхода топливных ресурсов для нужд теплоснабжения, что позволяет подключать к уже существующим ТЭЦ и котельным больше новых домов.

5. Использование ИТП позволяет оптимизировать режим работы тепловых сетей, что ведёт к повышению надёжности всей их работы.

6. Переход от четырёхтрубных к двухтрубным внутриквартальным системам доставки теплоты позволит дополнительно сократить тепловые потери и вдвое снизить эксплуатационные расходы теплоснабжающих организаций на их обслуживание.

7. Сокращает потребление электроэнергии сетевыми насосами.

Таким образом, вместо реконструкции ЦТП целесообразным на сегодня является полный отказ от них и переход на ИТП. Прогрессивная технология теплоснабжения избавит коммунальщиков от ежегодных проблем, связанных с началом отопительного сезона. Вместе с теплоизоляцией зданий, установкой радиаторных терморегуляторов и переводом потребителей на приборный учёт тепла, такое решение позволит добиться сокращения объёмов теплопотребления.

1. Ахмерова Г.М. Проблемы перехода от ЦТП на АИТП в Казани // Новости теплоснабжения. 2016. №5. С.37-39.

2. Залялова А. Р., Хасанов Г.М., Ахмерова Г.М. Проблемы систем централизованного теплоснабжения и пути их решения // Вестник научных конференций 2017. № 5-4(21) c. $55-56$.

3. Гайфуллина А. Р., Ахмерова Г.М. Особенности работы различных схем подогревателей горячего водоснабжения в тепловых пунктах // Вестник научных конференций 2017. № 4-3(20) - с. 34-36.

4. Гайфуллина А. Р., Замалтдинов А. Ф., Ахмерова Г.М. Специфика работы индивидуального теплового пункта // Вестник научных конференций 2017. № 4-3(20)c. $36-37$. 